\title{
Effect of pH on sorption kinetic process of acidic herbicides in a volcanic soil
}

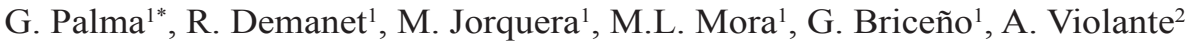 \\ ${ }^{I}$ Scientific and Technological Bioresource Nucleus (BIOREN). Universidad de La Frontera, Temuco, Chile. \\ ${ }^{2}$ Department of Agriculture. University of Naples Federico II, Via Università 10080055 Portici. Napoli. Italy. \\ ${ }^{*}$ Corresponding author: graciela.palma@ufrontera.cl.
}

\begin{abstract}
Kinetic studies of pesticides in soil are of great importance to know the processes and parameters that govern their fate in the environment. The aim of this study was to evaluate the influence of $\mathrm{pH}$ on the kinetic sorption process of four acidic herbicides, clopyralid, fluroxypyr, picloram and triclopyr on an Andisol, characterized by its high organic matter content and acidic $\mathrm{pH}$. The pseudo-second-order model appeared to fit the data better than other models $\left(\mathrm{R}^{2}>0.999\right)$. All herbicides were adsorbed rapidly during the first stage, but their adsorption was affected by $\mathrm{pH}$ and their chemical nature. The initial rates of reactions strongly decreased by increasing $\mathrm{pH}$. The initial adsorption rates (h) and the sorption capacity of the herbicides showed the following order fluroxypyr $>$ triclopyr $>$ picloram $>$ clopyralid. At $\mathrm{pH} 4.0$ the maximum amounts of fluroxypyr, triclopyr, picloram, and clopyralid adsorbed were respectively 75.2, 69.7, 40.5 and $11.7 \%$. The application of Elovich and Weber-Morris models suggests that mass transfer through the boundary layer and to a lesser degree intra-particle diffusion, control sorption kinetics, which appeared to be influenced by $\mathrm{pH}$ and chemical nature of the herbicides. The results obtained in this work suggest that soil $\mathrm{pH}$ and acidic character of herbicides could strongly affect the bioavailability of these herbicides on soil and their potential leaching.
\end{abstract}

Keywords: Acidic herbicides, sorption kinetic, Andisols, kinetic models

\section{Introduction}

Clopyralid, fluroxypyr, picloram and triclopyr are widely used in post-emergence to control broadleaf weeds in cereals, pastures and many other crops. They are systemic herbicides absorbed by the foliage and roots of plants. They are acidic herbicides with low $\mathrm{pK}_{\mathrm{a}}$ values (Table 1), and are then present in the anionic form within the $\mathrm{pH}$ range of soils and the environment (Tomlin, 1995; PPDB, 2013). Based on their chemical properties, there is a high risk of leaching to groundwater being these herbicides moderately toxic to animals (Cessna, 2002; AntunesKenyon and Kennedy, 2004; Palma et al., 2004; Messing et al., 2011; Lazartigues et al., 2013; Ulen et al., 2014).

They are weakly sorbed in soil through hydrophobic interactions and hydrogen bonding onto soil organic 
matter (OM), along with other suggested mechanisms for soils with low OM content (Kah and Brown, 2006). In general, it was established that the OM content and $\mathrm{pH}$ are the most important factors (but not independent) which affect sorption in soils, Furthemore, many authors have demonstrated that the adsorption of neutral molecule is largely influenced by the OM (Delle, 2001; Kah and Brown, 2006; Bukun et al., 2010; Assis et al., 2011).

Andisols are volcanic soils that are widely distributed around the world. They are variable surface charge and acidic $\mathrm{pH}$ soils, high in $\mathrm{OM}$ and allophane content. They have a high specific surface area, a low bulk density and high water retention capacity (Escudey et al., 2004).

Kinetic studies of pesticides in soil are of great importance to determine the parameters and processes involved in their sorption, being of agricultural and environmental relevance.

Sorption studies are usually conducted in apparent equilibrium conditions because that although and initial rapid sorption occurs, it may take a long time before the equilibrium is reached. The interaction of an herbicide with soil is a time dependent process which defines its bioavailability in soil. Sorption kinetic is characterized by a first rapid sorption stage followed by a second slower stage. According to Fernandez-Bayo et al (2008) this process occurs in three stages. The first stage is the diffusion of the pesticide to the surface of the sorbent called film mass transfer or boundary diffusion. The second stage, named particle difussion stage is slower, and is due to the diffusion of the solute within internal mesopores and micropores. The last stage, is the sorption of the solute in the interior surface of the sorbent through mass-action controlled mechanisms and rapid uptake occurs. There are few kinetic studies of pesticides in soil and particularly there are no published papers for these herbicides in Andisols, although studies have been reported for other acidic herbicides in these variables charges soils (Espinoza et al., 2009; Cáceres et al., 2010b). In this work we use models to establish kinetic parameters and modeling of sorption process, such as hiperbolic pseudo-first- and pseudo-secondorder and Elovich and Weber-Morris model used to describe solute transport mechanisms of organic compounds in soils (Azizian, 2004; Fernández-Bayo et al., 2008; Qiu et al., 2009; Cáceres et al., 2010a, 2010b).

The agronomic management involves urea fertilization before herbicide application with significant $\mathrm{pH}$ changes in soils (Campillo and Rodriguez, 1984; Mora et al., 2004; Cartes et al., 2009). Changes in soil $\mathrm{pH}$ under these conditions could strongly modify the sorption process and consequently mobility and degradation of acidic herbicides.

The aim of this study was to evaluate the influence of $\mathrm{pH}$ on the kinetic sorption process of four acid herbicide, clopyralid, fluroxypyr, picloram and triclopyr on an Andisol characterized by its high organic matter content and acidic $\mathrm{pH}$. Kinetic parameters were determined using the hyperbolic, pseudo-first-order and pseudo-second-order models and mechanistic aspects were analyzed using the Elovich and Weber-Morris models.

\section{Materials and Methods}

\subsection{Herbicides}

The herbicides used were: clopyralid (3,6-dichloropyridine-2-carboxylic acid), fluroxypyr (4-amino-3,5-dichloro-6-fluoro-2-pyridyloxyacetic acid), picloram (4-amino-3,5,6-trichloropyridine2-carboxylic acid) and triclopyr (3,5,6-trichloro-2pyridyloxyacetic acid). The analytical standards of herbicides were provided by Chem Service (West 
Chester, USA). All reagents used were analytical or HPLC grade.

\subsection{Soil}

An Andisol from southern Chile, belonging to the Freire family $\left(38^{\circ} 50^{\prime} \mathrm{S}\right.$ and $\left.72^{\circ} 35^{\prime} \mathrm{W}\right)$, which is medial, mesic, Typic Placudands, with a silty loam texture was used (CIREN, 2002). Soil samples were collected from the surface layer $(0-20 \mathrm{~cm})$, air dried, and sieved through a 2-mm mesh and characterized according to the methods described in Sadzawka et al., (2006). Briefly, the OM content was measured using the Walkley - Black method. The $\mathrm{pH}$ was measured in soil suspensions with deionized water at 1:2.5 (w/v) ratio and with $0.01 \mathrm{M} \mathrm{CaCl}_{2}$. Cation exchange capacity (CEC) was calculated from the total exchangeable bases $(\mathrm{Mg}, \mathrm{Ca}, \mathrm{K}$, and $\mathrm{Na}$ extracted by $1 \mathrm{M}$ ammonium acetate at $\mathrm{pH}$ 7.0) and analyzed by flame atomic absorption spectrophotometry. Table 2 shows the main properties of the Andisol under investigation.

\subsection{Adsorption kinetics}

Duplicate sample of $2.0 \mathrm{~g}$ soil were placed in 50 $\mathrm{mL}$ centrifuge tubes (polypropylene copolymer), and mixed with approximately $18 \mathrm{~mL}$ of a $0.01 \mathrm{M}$ $\mathrm{CaCl}_{2}$ aqueous solution. Small volumes of $\mathrm{HCl}$ and $\mathrm{NaOH} 1 \mathrm{M}$ were added to adjust $\mathrm{pH}$ at 4.0, 5.0 and 6.0. Preliminary tests were conducted in presence of herbicides to determine the minimum volume of acid or alkali solution required to reach $\mathrm{pH} 4,5$ or 6 . Finally, each herbicide prepared in a $0.01 \mathrm{M} \mathrm{CaCl}_{2}$ aqueous solution was added to result in a concentration of 1.0 $\mathrm{mg} \mathrm{L}^{-1}$ in a final volume of $20 \mathrm{~mL}$. The tubes were shaken at $20 \pm 1^{\circ} \mathrm{C}$ in a rotary shaker for 1-24 hours. Subsamples were removed at different intervals of times, centrifuged at $2065 \mathrm{~g}$ for $15 \mathrm{~min}$ and filtered using $0.22 \mu \mathrm{m}$ membranes (Durapore, PVDF from
Millipore) and transferred to HPLC vials for analysis. Sorption experiments were repeated twice. For all experiments the final $\mathrm{pH}$ was 4,5 or $6 \pm 0.1$.

\subsection{Herbicide analysis}

The herbicides were analyzed using a Shimadzu Prominence HPLC chromatograph LC-20AT with a diode array detector (SPD-M20A), using a prontoSil column RP-C18 (250x4.6 mm). The mobile phase used was a 50:50 (v/v) mix of acetonitrile and water acidified to $\mathrm{pH} 2$ with phosphoric acid. The detection wave-length was $225 \mathrm{~nm}$ for all herbicides. The injection volume was $20 \mu 1$, the flow $1.0 \mathrm{~mL} \mathrm{~min}^{-1}$ and the oven temperature $30{ }^{\circ} \mathrm{C}$. Calibration curves were prepared for each herbicide.

\subsection{Kinetic models}

\subsubsection{Hyperbolic model}

The linear form of this model (Equation 1) enables us to obtain some sorption parameter values by fitting it to experimental data. Where $\mathrm{q}_{\mathrm{t}}$ is the sorbed quantity $\left(m g \mathrm{~kg}^{-1}\right)$ at time $\mathrm{t} ; \mathrm{q}_{\max }\left(\mathrm{mg} \mathrm{kg}^{-1}\right)$ is the maximum sorbed amount; $\mathrm{t}(\mathrm{h})$ is the solid-solution contact time, and $\mathrm{B}$ is an empirical constant.

$$
\frac{1}{q_{t}}=\frac{B}{q \max } \frac{1}{t}+\frac{1}{q_{\max }}
$$

\subsubsection{Pseudo-first-order kinetic reaction model}

Some sorption parawmeter by fitting it to the experimental data, where obtained, $\mathrm{q}_{\mathrm{t}}\left(\mathrm{mg} \mathrm{kg}^{-1}\right), \mathrm{q}_{\max }$ $\left(\mathrm{mg} \mathrm{kg}^{-1}\right)$, are similarly defined as in the hyperbolic model, and $k_{l}\left(\mathrm{~h}^{-1}\right)$ correspond to the first-order rate constant (Equation 2) 


$$
\log \left(q_{\max }-q_{t}\right)=\log q_{\max }-\frac{k_{1}}{2.303} t
$$

\subsubsection{Pseudo-second-order kinetic reaction model}

This model (Equation 3) assumes that the sorption capacity could be proportional to the number of active soil sites, where $\mathrm{q}_{\mathrm{t}}$ and $\mathrm{q}_{\max }$ have the same definition as in the previous models and $k_{2}\left(\mathrm{mg} \mathrm{kg}^{-1} \mathrm{~h}^{-1}\right)$ is the reaction-rate constant.

$$
\frac{t}{q_{t}}=\frac{1}{q_{\max }^{2} k_{2}}+\frac{t}{q_{\max }}
$$

\subsubsection{Elovich equation}

This equation establishes that the sorption kinetics take place in two phases. A rapid initial stage associated with the movement of the pesticide to the most accessible parts of the soil, followed by a slower second stage where diffusion particles in soil micropores occur. The linear form is written in Equation 4, where $\mathrm{q}_{\mathrm{t}}$ is the sorbed quantity ( $\mathrm{mg}$ $\left.\mathrm{kg}^{-1}\right)$ at time t, and $X$ and $Y$ are empirical constants. The intersect $\left(1 / Y \ln \left(\begin{array}{ll}X & Y\end{array}\right)\right)$ correspond to the sorbed quantity for the fast phase and the slope $1 / y$, represents the duration of second phase.

$q_{t}=\frac{1}{Y} \ln (x y)+\frac{1}{Y} \ln t$

\subsubsection{Weber-Morris model}

This equation (Equation 5) establishes that many sorption processes vary proportionally with $t^{1 / 2}$, where $\mathrm{q}_{\mathrm{t}}$ is the pesticide adsorbed $\left(\mathrm{mg} \mathrm{kg}^{-1}\right)$ at time $\mathrm{t}$, $\mathrm{C}\left(\mathrm{mg} \mathrm{kg}^{-1}\right)$ is a constant related to the the thickness of the boundary layer and $k_{\text {int }}\left(\mathrm{mg} \mathrm{kg}^{-1} \mathrm{~h}^{-1 / 2}\right)$ is the intraparticle diffusion rate constant.

$$
q_{t}=k_{\text {int }} t^{1 / 2}+C
$$

\section{Results and Discussion}

The effect of $\mathrm{pH}$ on the equilibrium between neutral and anionic forms of both herbicides is shown in Table 1. This relationship, pKa-dependent, is fundamental to understand the sorption processes of these acidic herbicides on soils. Neutral form of each herbicide were present at $\mathrm{pH} 4.0$, but their concentration decreasing by increasing $\mathrm{pH}$. The percentages of neutral forms of clopyralid, fluroxypyr, picloram and triclopyr at pH4 were approximately 1, 7, 2.0 and $50 \%$ respectively (Schwarzenbach et al., 2003).

For these herbicides no kinetics studies are reported in literature. However, some authors ascertained that the adsorption of these herbicides was affected by $\mathrm{OM}$ and $\mathrm{pH}$ and that these substances were weakly sorbed on OM through hydrophobic interactions and hydrogen bonding (Delle, 2001; Kah and Brown, 2006, 2007; Bukun et al., 2010; Assis et al., 2011). 
Table 1. Some properties of herbicides

\begin{tabular}{lllllll}
\hline Herbicide & $\mathrm{Sw}^{\mathrm{a}}\left(\mathrm{g} \mathrm{L}^{-1}\right)$ & $\log \mathrm{P}^{\mathrm{b}}$ & $\mathrm{pK}_{\mathrm{a}}$ & \multicolumn{2}{c}{$\alpha^{\mathrm{c}}(\%)$} \\
\hline
\end{tabular}

${ }^{a}$ Water solubility. ${ }^{b} \log$ P, octanol-water partition coefficient. ${ }^{c}$ neutral form of herbicide (\%). (Source: Tomlin 1995; PPDB, 2013.

Figure 1, 2, 3, 4 show the sorption kinetics of clopyralid, fluroxypyr, picloram and triclopyr, respectively at $\mathrm{pH} 4,5$ and 6. The sorption capacityof these herbicides was in the order fluroxypyr $>$ triclopyr $>$ picloram $>$ clopyralid. The quantities of clopyralid adsorbed in the first 15 minutes at pH 4, 5 and 6 was 8.6, 4.0 and 2.0\%, respectively. (Figure 1). For fluroxypyr they were $67.8,50.5$ and $33.6 \%$. (Figure 2). For picloram 34.1, 18.9 and 13.0\% (Figure 3) and, finally, for triclopyr 60.2, 38.3 and 26.6\%. (Figure 4). The sorption of all the herbicides increased quickly during this short herbicide solution-soil contact time, followed by much slower stage progressing towards an apparent equilibrium to 24 hours. After 24 hours, at $\mathrm{pH}$ 4 , the amount of clopyralid, fluroxypyr, picloram and triclopyr, adsorbed were 11.7, 75.2, 40.5 and 69,7\%, respectively. 


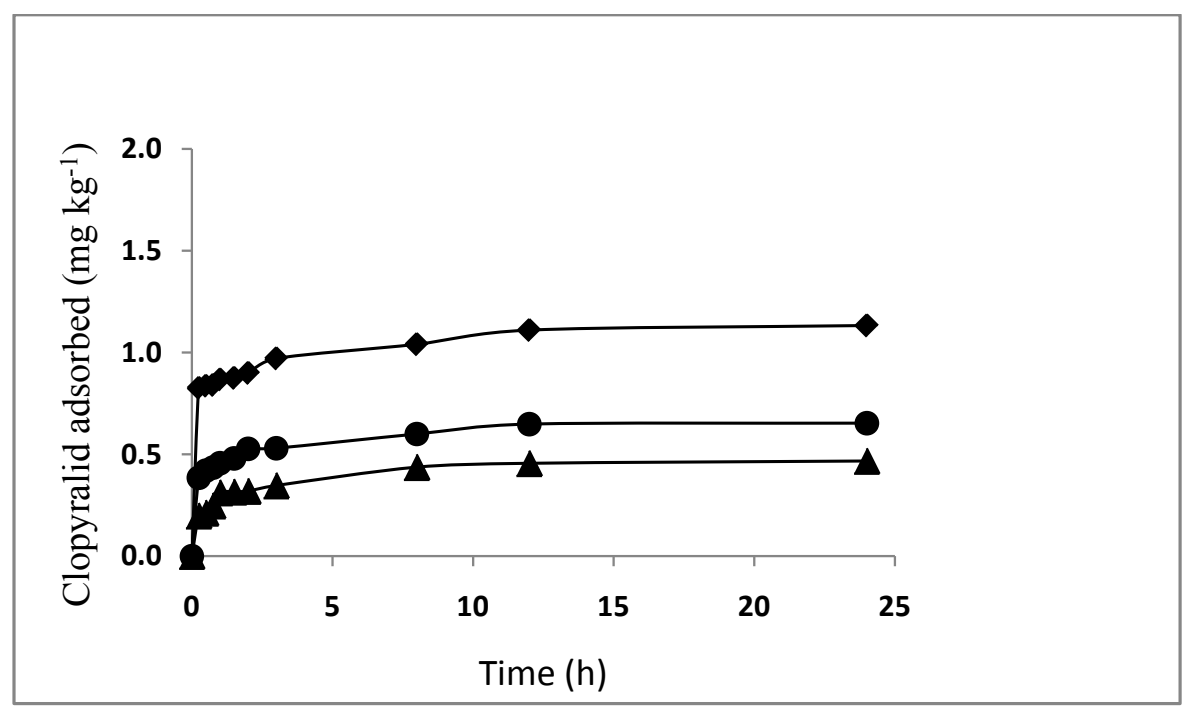

Figure 1. Sorption kinetics of clopyralid at pH $4(\bullet), \mathrm{pH} 5(\bullet)$ and $\mathrm{pH} 6(\boldsymbol{\Delta})$

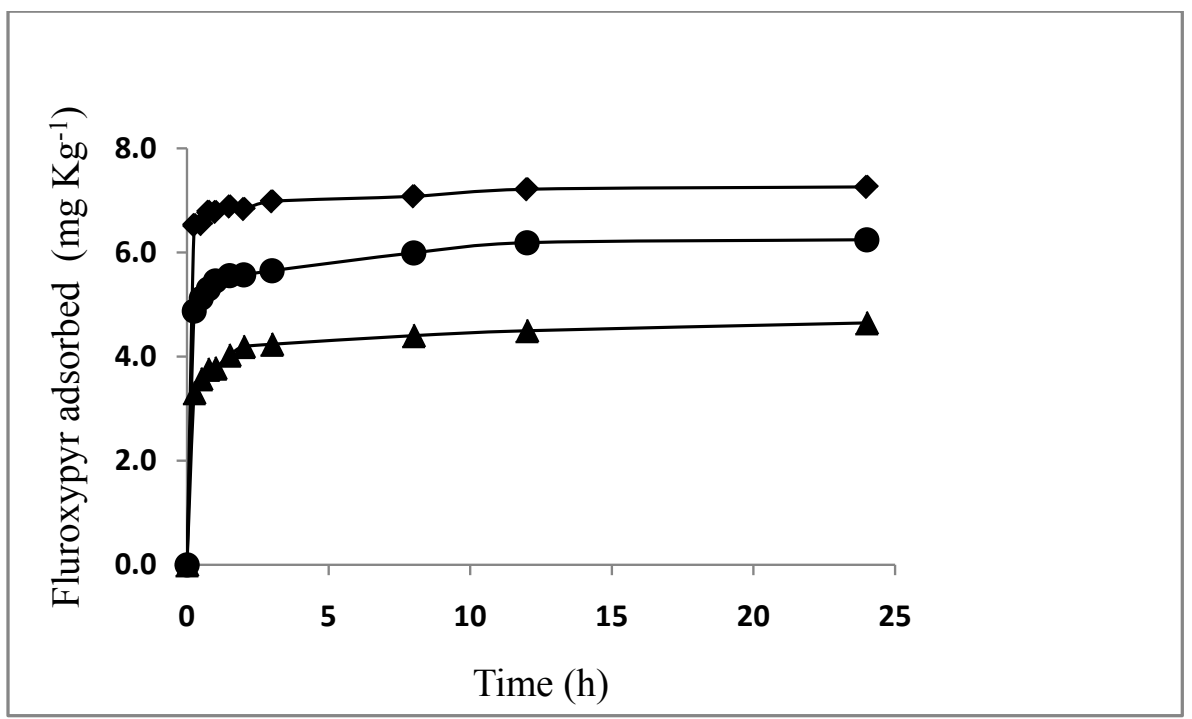

Figure 2. Sorption kinetics of fluroxypyr at pH $4(\bullet), \mathrm{pH} 5(\bullet)$ and $\mathrm{pH} 6(\boldsymbol{\Delta})$ 


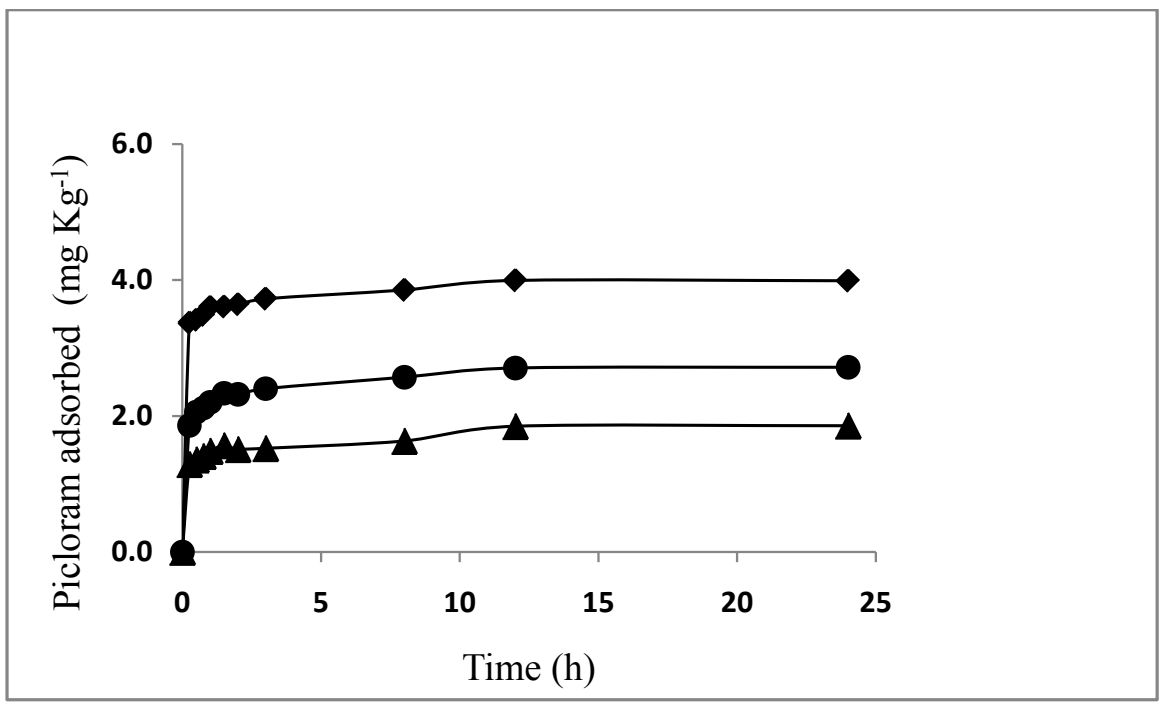

Figure 3. Sorption kinetics of picloram at pH $4(\bullet), \mathrm{pH} 5(\bullet)$ and $\mathrm{pH} 6(\boldsymbol{\Delta})$

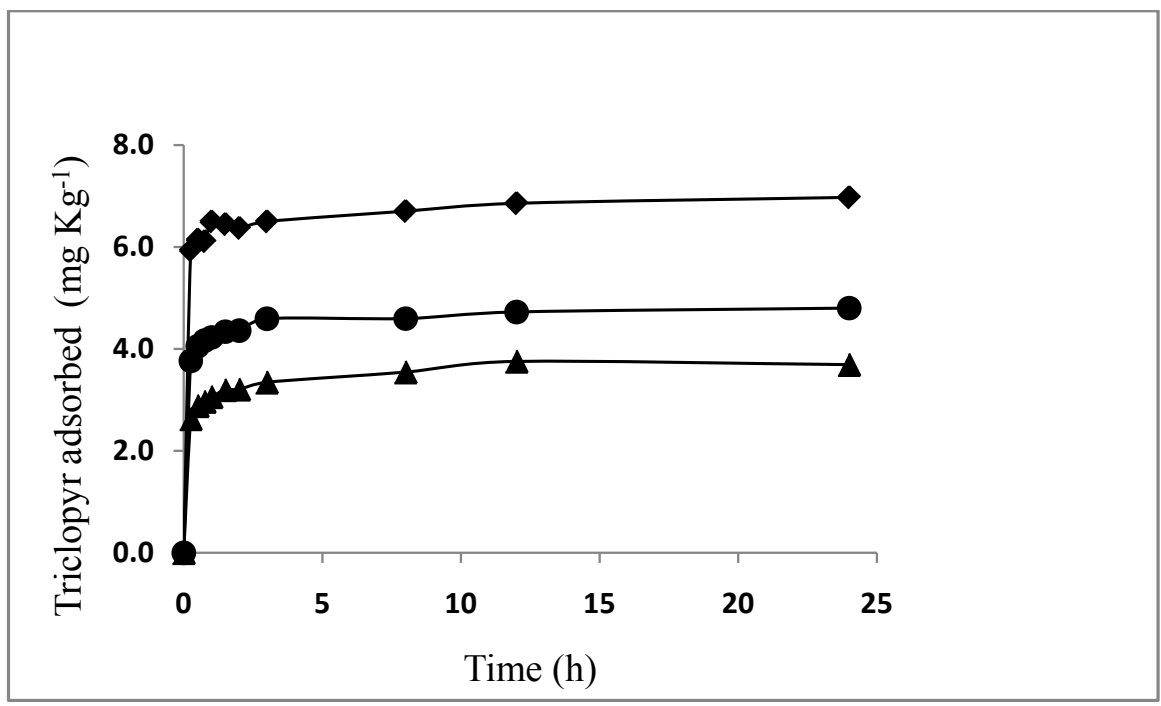

Figure 4. Sorption kinetics of triclopyr at pH $4(\bullet), \mathrm{pH} 5(\bullet)$ and $\mathrm{pH} 6(\boldsymbol{\Delta})$ 
These results are in accordance with some properties of herbicides reported in Table 1 , as $\log \mathrm{P}$, which indicates a greater hydrophobic character for triclopyr and fluroxypyr compared to picloram and clopyralid. Besides, within the range of $\mathrm{pH}$ studied, the percentages of neutral form of triclopyr and fluroxypyr are much higher than those of picloram and clopyralid. Furthermore at low $\mathrm{pH}$ values picloram and fluroxypyr may be partially in cationic form due to protonation of amino groups with a consequent higher adsorption capacity of these herbicides (Assis et al., 2011). On the other hand, it is know that the $\mathrm{pH}$ in the soil surface may be lower than in the soil solution, meaning that a higher number of neutral herbicide molecules could be available to be adsorbed. On the surface of OM the $\mathrm{pH}$ might be 0.2-0.5 unit lower than liquid phase. Kinetic studies carried out on Andisol for metsulfuronmethyl (Caceres 2010a), atrazine (Baez et al., 2013) and diuron (Caceres et al., 2013) have shown similar behavior, with a rapid initial stage followed by a slower second stage to reach an apparent equilibrium over time.

Different kinetic models were applied to the experimental data in order to determine the kinetic parameters and information on the adsorption mechanisms involved (Table 3, 4).

For hyperbolic model the determination coefficients $\left(\mathrm{R}^{2}\right)$, used to evaluate the model fit were lower $(0.70<$ $\mathrm{R}^{2}<0.89$ ), although $\mathrm{q}_{\max }$ values are near experimental values (Table 3, 4). For pseudo-first-order model the $\mathrm{R}^{2}$ values showed a good fit $\left(0.86<\mathrm{R}^{2}<0.99\right)$. However, the $\mathrm{q}_{\max }$ value given by the model differed largely from experimental $\mathrm{q}_{\operatorname{maxxp}}$ estimated from experimental data at 24 hours (Table 3, 4).

The pseudo-second-order model shows a good fit with the experimental data, with $\mathrm{R}^{2}$ values $>0.99$ for all $\mathrm{pHs}$ and herbicides. The $\mathrm{q}_{\max }$ values obtained are consistent with experimental values (Table 3,
4). For the four herbicides, clopyralid showed the highest kinetic rate constant $\left(k_{2}\right)$. There are marked differences in the first stage of the adsorption process according to the values of the initial rate constant $\left(\mathrm{h}=\mathrm{qmax}^{2} k_{2}\right.$ ), obtained from the intercept of pseudosecond-order equation (Equation 3). In general, $h$ showed the following order fluroxypyr $>$ triclopyr $>$ picloram > clopyralid. At $\mathrm{pH} 4$, where there are a greater amount of neutral molecules of herbicides, $h$ values approximately were $83,50,28$ and $3.0 \mathrm{mg} \mathrm{kg}^{-1}$ $\mathrm{h}^{-1}$ (Table 3, 4). At higher pHs, the initial rate deeply decreased for all herbicides.

The Elovich model (Equation 4), used to describe the pseudo-second-order kinetics fit well for all herbicides $\left(\mathrm{R}^{2}>0.92\right)$ (Table 3, 4). From the Elovich linear equation, the intercept $(1 / Y)(\ln X Y)$ is considered the amount sorbed during initial equilibrium phase (fast phase reaction) and $1 / Y$ is the sorption rate as a function of time during the slow phase of the reaction (Caceres et al 2010a). The herbicide amount sorbed during the fast phase ranged between 92-82, 90$81,89-78$ and $77-58 \%$ of the total sorbed amount, for fluroxypyr, triclopyr, picloram and clopyralid, respectively, indicating an almost instantaneous adsorption equilibrium for all herbicides, except clopyralid, which present the lowest h value.

In general, coefficient $(1 / Y)$ values for all herbicides were very lower compared con $\mathrm{h}$ values and no dependence with $\mathrm{pH}$ was obtained Table 3, 4).

The Weber-Morris model relates $\mathrm{q}_{\mathrm{t}}$ versus $\mathrm{t}^{1 / 2}$ generating straight line that passes through the origin (Equation 5) when the intra particle diffusion process controls the sorption mechanism. C intersect values provide information relate of the thickness of the boundary layer, a larger value meaning a higher boundary layer effect. Table 3 an Table 4 shows the kinetic parameters obtained for this model. The model shows a good fit for all herbicides $\left(0.76<\mathrm{R}^{2}<0.94\right)$, but the line no pass through the origin, with $\mathrm{C}$ values different to zero. Then, 
the boundary layer that surround soil particles have an important effect on the initial sorption kinetics for all herbicides, being the lowest for clopyralid. These results are in accordance with those obtained for Cáceres et al. (2010a) who studied the sorption behavior of metsulfuron-methyl $(\mathrm{pKa}=3.3)$ on Andisols. In these soils, mass transfer across the boundary layer, and in a lesser degree, intraparticle diffusion were the two processes that control sorption kinetic. In this study,
Cáceres et al. (2010a) compared the herbicide behavior in Ultisols and Andisol concluding that the mineral fraction and $\mathrm{OM}$, respectively define the processes that control sorption kinetic. In Ultisols intraparticle diffusion was the mainly processes. Others studies on the adsorption of atrazine (weak base) and diuron (Baez et al., 2013; Caceres et al., 2013) on Chilean Andisols and Ultisols have shown a behavior similar to that of metsulfuronmethyl in these soils.

Table 2. Selected properties of studied Andisol soil

\begin{tabular}{llllllll}
\hline $\mathrm{pH}_{\mathrm{H} 2 \mathrm{O}}$ & $\mathrm{pH}_{\mathrm{CaCl} 2}$ & $\mathrm{OM}^{\mathrm{a}}(\%)$ & $\mathrm{CEC}^{\mathrm{b}}\left(\mathrm{cmol}_{(+)} / \mathrm{kg}\right)$ & Sand (\%) & Silt $(\%)$ & $\mathrm{Clay}(\%)$ & Texture \\
\hline 5.68 & 4.76 & 15.0 & 8.20 & 39.7 & 42.9 & 17.3 & Silty loam \\
\hline Mean Values, $n=3 .{ }^{\mathrm{a}}$ Organic matter. ${ }^{+C a t i o n}$ exchange capacity.
\end{tabular}

Table 3. Kinetic parameters from linear analysis of hiperbolic model, pseudo-first-order, pseudo-second-order, Weber-Morris and Elovich kinetic models of fluroxypyr and triclopyr on Andisol soil at pH 4, 5 and 6

\begin{tabular}{|c|c|c|c|c|c|c|}
\hline Herbicide & Fluroxypyr & & & Triclopyr & & \\
\hline $\mathrm{pH}$ & 4 & 5 & 6 & 4 & 5 & 6 \\
\hline $\mathbf{q}_{\max \exp }\left(\mathrm{mg} \mathrm{kg}^{-1}\right)$ & $7.26 \pm 0.04^{\mathrm{a}}$ & $6.24 \pm 0.02$ & $4.65 \pm 0.12$ & $6.97 \pm 0.060$ & $4.80 \pm 0.01$ & $3.69 \pm 0.04$ \\
\hline \multicolumn{7}{|l|}{ Hiperbolic } \\
\hline $\mathrm{q}_{\max }\left(\mathrm{mg} \mathrm{kg}^{-1}\right)$ & $7.09 \pm 0.12^{b}$ & $5.92 \pm 0.20$ & $4.39 \pm 0.16$ & $6.71 \pm 0.20$ & $4.63 \pm 0.20$ & $3.50 \pm 0.18$ \\
\hline $\mathrm{R}^{2}$ & 0.732 & 0.818 & 0.881 & 0.740 & 0.895 & 0.854 \\
\hline \multicolumn{7}{|l|}{ Pseudo-first-order } \\
\hline $\mathrm{q}_{\max }\left(\mathrm{mg} \mathrm{kg}^{-1}\right)$ & $0.69 \pm 0.16$ & $1.07 \pm 0.06$ & $1.07 \pm 0.03$ & $1.04 \pm 0.03$ & $0.72 \pm 0.08$ & $0.79 \pm 0.03$ \\
\hline$k_{1}\left(h^{-1}\right)$ & $0.14 \pm 0.04$ & $0.18 \pm 0.01$ & $0.17 \pm 0.01$ & $0.24 \pm 0.01$ & $0.20 \pm 0.01$ & $0.10 \pm 0.02$ \\
\hline $\mathrm{R}^{2}$ & 0.981 & 0.988 & 0.960 & 0.944 & 0.963 & 0.903 \\
\hline \multicolumn{7}{|l|}{ Pseudo-second-order } \\
\hline $\mathrm{q}_{\max }\left(\mathrm{mg} \mathrm{kg}^{-1}\right)$ & $7.30 \pm 0.01$ & $6.29 \pm 0.01$ & $4.67 \pm 0.02$ & $6.99 \pm 0.01$ & $4.83 \pm 0.01$ & $3.75 \pm 0.02$ \\
\hline $\mathrm{k}_{2}\left(\mathrm{~kg} \mathrm{mg}^{-1} \mathrm{~h}^{-1}\right)$ & $1.56 \pm 0.02$ & $0.84 \pm 0.02$ & $0.90 \pm 0.02$ & $1.02 \pm 0.01$ & $1.30 \pm 0.02$ & $1.21 \pm 0.02$ \\
\hline $\mathrm{h}\left(\mathrm{mg} \mathrm{kg}^{-1} \mathrm{~h}^{-1}\right)$ & 83.33 & 33.33 & 19.61 & 50.00 & 30.30 & 16.95 \\
\hline $\mathrm{R}^{2}$ & 0.999 & 0.999 & 0.999 & 0.999 & 0.999 & 0.999 \\
\hline \multicolumn{7}{|l|}{ Elovich } \\
\hline$(1 / y) \ln x y\left(\mathrm{mg} \mathrm{kg}^{-1}\right)$ & $6.76 \pm 0.04$ & $5.37 \pm 0.01$ & $3.82 \pm 0.02$ & $6.29 \pm 0.2$ & $4.20 \pm 0.03$ & $3.04 \pm 0.02$ \\
\hline $1 / \mathrm{y}\left(\mathrm{mg} \mathrm{kg}^{-1}\right)$ & $0.17 \pm 0.02$ & $0.30 \pm 0.02$ & $0.29 \pm 0.02$ & $0.22 \pm 0.01$ & $0.21 \pm 0.01$ & $0.24 \pm 0.00$ \\
\hline $\mathrm{R}^{2}$ & 0.956 & 0.981 & 0.955 & 0.926 & 0.939 & 0.968 \\
\hline \multicolumn{7}{|l|}{ Weber-Morris } \\
\hline $\mathrm{k}_{\text {int }}\left(\mathrm{mg} \mathrm{kg}^{-1} \mathrm{~h}^{1 / 2}\right)$ & $0.16 \pm 0.02$ & $0.29 \pm 0.02$ & $0.27 \pm 0.02$ & $0.21 \pm 0.01$ & $0.20 \pm 0.03$ & $0.23 \pm 0.02$ \\
\hline $\mathrm{C}\left(\mathrm{mg} \mathrm{kg}^{-1}\right)$ & $6.59 \pm 0.10$ & $5.06 \pm 0.10$ & $3.54 \pm 0.08$ & $6.06 \pm 0.20$ & $3.99 \pm 0.40$ & $2.80 \pm 0.10$ \\
\hline $\mathrm{R}^{2}$ & 0.837 & 0.853 & 0.779 & 0.827 & 0.756 & 0.812 \\
\hline
\end{tabular}

$\mathrm{q}_{\max \exp }$ at $24 \mathrm{~h} .{ }^{\mathrm{b}}$ Standard deviations for $n=4$ 
Table 4. Kinetic parameters from linear analysis of hiperbolic model, pseudo-first-order, pseudo-second-order, Weber-Morris and Elovich kinetic models of clopyralid and picloram on Andisol soil at $\mathrm{pH} \mathrm{4,5}$ and 6

\begin{tabular}{|c|c|c|c|c|c|c|}
\hline \multirow{2}{*}{$\begin{array}{l}\text { Herbicide } \\
\mathrm{pH}\end{array}$} & \multicolumn{3}{|l|}{ Clopyralid } & \multicolumn{3}{|l|}{ Picloram } \\
\hline & 4 & 5 & 6 & 4 & 5 & 6 \\
\hline $\mathbf{q}_{\max \exp }\left(\mathrm{mg} \mathrm{kg}^{-1}\right)$ & $1.14 \pm 0.04^{\mathrm{a}}$ & $0.66 \pm 0.04$ & $0.47 \pm 0.02$ & $4.00 \pm 0.02$ & $2.72 \pm 0.02$ & $1.86 \pm 0.01$ \\
\hline $\mathrm{q}_{\max }\left(\mathrm{mg} \mathrm{kg}^{-1}\right)$ & $0.99 \pm 0.20^{\mathrm{b}}$ & $0.57 \pm 0.20$ & $0.40 \pm 0.20$ & $3.82 \pm 0.12$ & $2.55 \pm 0.20$ & $1.67 \pm 0.16$ \\
\hline $\mathrm{R}^{2}$ & 0.732 & 0.769 & 0.837 & 0.704 & 0.865 & 0.714 \\
\hline \multicolumn{7}{|l|}{ Pseudo-first-order } \\
\hline $\mathrm{q}_{\max }\left(\mathrm{mg} \mathrm{kg}^{-1}\right)$ & $0.34 \pm 0.12$ & $0.25 \pm 0.08$ & $0.23 \pm 0.04$ & $0.57 \pm 0.02$ & $0.67 \pm 0.02$ & $0.54 \pm 0.03$ \\
\hline $\mathrm{k}_{1}\left(\mathrm{~h}^{-1}\right)$ & $0.20 \pm 0.01$ & $0.09 \pm 0.01$ & $0.10 \pm 0.01$ & $0.15 \pm 0.01$ & $0.22 \pm 0.01$ & $0.15 \pm 0.00$ \\
\hline $\mathrm{R}^{2}$ & 0.994 & 0.874 & 0.857 & 0.959 & 0.968 & 0.933 \\
\hline \multicolumn{7}{|l|}{ Pseudo-second-order } \\
\hline $\mathrm{q}_{\max }\left(\mathrm{mg} \mathrm{kg}^{-1}\right)$ & $1.14 \pm 0.01$ & $0.66 \pm 0.01$ & $0.48 \pm 0.02$ & $4.02 \pm 0.01$ & $2.75 \pm 0.01$ & $1.87 \pm 0.02$ \\
\hline $\mathrm{k}_{2}\left(\mathrm{~kg} \mathrm{mg}^{-1} \mathrm{~h}^{-1}\right)$ & $2.30 \pm 0.02$ & $3.18 \pm 0.02$ & $2.84 \pm 0.02$ & $1.72 \pm 0.01$ & $1.35 \pm 0.02$ & $1.41 \pm 0.02$ \\
\hline $\mathrm{h}\left(\mathrm{mg} \mathrm{kg}^{-1} \mathrm{~h}^{-1}\right)$ & 3.00 & 1.40 & 0.66 & 27.78 & 10.20 & 4.95 \\
\hline $\mathrm{R}^{2}$ & 0.999 & 0.999 & 0.999 & 0.999 & 0.999 & 0.998 \\
\hline \multicolumn{7}{|l|}{ Elovich } \\
\hline$(1 / y) \ln x y\left(\mathrm{mg} \mathrm{kg}^{-1}\right)$ & $0.88 \pm 0.02$ & $0.46 \pm 0.01$ & $0.28 \pm 0.02$ & $3.56 \pm 0.02$ & $2.19 \pm 0.03$ & $1.46 \pm 0.02$ \\
\hline $1 / \mathrm{y}\left(\mathrm{mg} \mathrm{kg}^{-1}\right)$ & $0.08 \pm 0.02$ & $0.06 \pm 0.02$ & $0.06 \pm 0.00$ & $0.15 \pm 0.01$ & $0.19 \pm 0.00$ & $0.12 \pm 0.00$ \\
\hline $\mathrm{R}^{2}$ & 0.938 & 0.980 & 0.965 & 0.973 & 0.975 & 0.923 \\
\hline \multicolumn{7}{|l|}{ Weber-Morris } \\
\hline $\mathrm{k}_{\text {int }}\left(\mathrm{mg} \mathrm{kg}^{-1} \mathrm{~h}^{1 / 2}\right)$ & $0.08 \pm 0.02$ & $0.06 \pm 0.02$ & $0.06 \pm 0.02$ & $0.15 \pm 0.01$ & $0.18 \pm 0.00$ & $0.12 \pm 0.01$ \\
\hline $\mathrm{C}\left(\mathrm{mg} \mathrm{kg}^{-1}\right)$ & $0.79 \pm 0.06$ & $0.38 \pm 0.10$ & $0.21 \pm 0.08$ & $3.40 \pm 0.06$ & $1.20 \pm 0.04$ & $1.32 \pm 0.08$ \\
\hline $\mathrm{R}^{2}$ & 0.939 & 0.885 & 0.854 & 0.874 & 0.828 & 0.879 \\
\hline
\end{tabular}

\section{Conclusions}

Kinetic studies concluded that a large amount of all herbicides are adsorbed in the rapid first stage, depending on the $\mathrm{pH}$, followed by much lower adsorption in the slower second stage. The kinetic data was found to follow closely the pseudo-second-order kinetic model. In Andisols, characterized by a high content of organic matter is the its main characteristic, the mass transfer across the boundary layer, and, in a lesser degree, intraparticle diffusion mechanisms controlled the adsorption kinetics of the herbicides. The adsorption kinetic was affected by $\mathrm{pH}$ and chemical nature of the herbicides, according the pseudo-secondorder kinetic reaction, Elovich and Weber-Morris models. These results suggest that soil $\mathrm{pH}$ and chemical nature of the herbicide could have a strong influence on their mobility in soils and then on their bioavailability.

\section{Acknowledgments}

This study was financed by Project FONDECYT 1120467, from CONICYT, Chile.

\section{References}

Antunes-Kenyon, S., Kennedy, G. 2004. A review of the toxicity and environmental fate of triclopyr. Massachusetts Department of Agricultural Resources. 47 p.

Assis, E., Silva,A., Barbosa, L., Queiroz, M., Dantonino, L., Cruz, L. 2011. Sorption and desorption of picloram in soils under pasture in Brazil. Planta Daninha 29, 893-899. 
Azizian, S. 2004. Kinetic models of sorption: a theorical analysis. J. Colloid Interf. Sci. 276, 47-52.

Baez, M.E., Fuentes, E., Espinoza, J. 2013. Characterization of the atrazine sorption process on Andisol and Ultisol volcanic ash-derived soils: kinetic parameters and the contribution of humic fractions. J. Agric. Food Chem. 61, 6150-6160.

Bukun, B., Shaner, D., Nissen, S., Westra, P., Brunk ,G. 2010. Comparison of the interaction of aminopiralid vs. clopyralid with soil. Weed Sci. 58, 473-477.

Cáceres, L., Escudey, M., Fuentes, E., Báez, M.E. 2010a. Modeling the sorption kinetic of metsulfuron-methyl on Andisols and Ultisols volcanic ash-derived soils: kinetics parameters and solute transport mechanisms. J. Hazard. Mater. 179, 795-803.

Cáceres, L., Fuentes, R., Escudey, M., Fuentes, E. Baez, M.E. 2010b. Metsulfuron-methyl sorption/ desorption behavior on volcanic ash-derived soils. Effect of Phosphate and pH. J. Agric. Food Chem. 58, 6864-6869.

Cáceres, L., Rodríguez, R., Parra, J., Escudey, M., Barrientos, L. Castro, V. 2013. Sorption kinetics of diuron on volcanic ash derived soils. J. Hazard. Mater. 261, 602-6013.

Campillo, R., Rodriguez, S. 1984. Acidifying effect of urea transformation in two Andisols of the Lake Region. Agricultura Técnica. (Chile). 44, 131138.

Cartes, P., Jara, A., Demanet, R., Mora, M.L. 2009. Urease activity and nitrogen mineralization kinetics as affected by temperature and urea input rate in southern chilean andisols. J. Soil Sc. Plant Nutr. 9, 69-82.

Cessna, A. 2002. Environmental fate of triclopyr. Reviews of Environmental Contamination and Toxicology. 174, 19-48.
CIREN, 2002. Estudio Agrológico, IX Región. Descripciones de Suelos, Materiales y Símbolos. Centro de Información de Recursos Naturales, Santiago, Publicación 122, 660 p.

Delle, S.A. 2001. Factors affecting sorption of organic compounds in natural sorbent/water systems and sorption coefficients for selected pollutants. A Review. J. Phys. Chem. Ref. Data. 30, 187-439.

Escudey, M., Forster, J., Galindo, G. 2004. Relevance of organic matter in some chemical and physical characteristics of volcanic ash-derived soils. Commun. Soil Sci. Plant Anal. 35, 781-797.

Espinoza, J., Fuentes, E., Báez, M.E. 2009. Sorption behavior of bensulfuron-methyl on andisols and ultisols volcanic ashderived soils: Contribution of humic fractions and mineral-organic complexes. Environ. Pollut. 157, 3387-3395.

Fernandez-Bayo, J., Nogales, R., Romero, E. 2008. Evaluation of the sorption process for imidacloprid and diuron in eight agricultural soils from southern Europe using various kinetic models. J. Agric. Food Chem. 56, 5266-5272.

Kah, M., Brown, C.D. 2006. Adsorption of ionisable pesticides in soils. Rev. Environ. Contam. Toxicol. 188, 149-217.

Kah, M., Brown, C.D. 2007. Prediction of the adsorption of ionizable pesticides in soils. J. Agric. Food Chem. 55, 2312-2322.

Lazartigues, A., Thomas, M., Cren-Olive, C., Brunbellut, J., Le Roux, Y., Banas, D., Feidt, C. 2013. Pesticide pressure and fish farming in barrage pond in Northeastern France. Part II: residues of 13 pesticides in water, sediments, edible fish and their relationships. Environ. Sci. Pollut. Res. 20, 117-125.

Messing, P., Farenhorst, A., Waite, D., McQeen, D., Sproull, J., Humphries, D., Thomson, L. 2011. Prediction wetland contamination from atmospheric deposition measurements of 
pesticides in the Canadian Prairie Pothole region. Atmospheric Environment. 45, 7227-7234.

Mora, M.L., Alfaro, M., Williams, P., Stehr, W., Demanet, R. 2004. Effect of fertiliser input on soil acidification in relation to growth and chemical composition of a pasture, and animal production. R.C. Suelo Nutr. Veg. 4, 29-40.

Palma, G.A., Sanchez, Y., Olave, F., Encina, R., Palma, R., Barra. 2004. Pesticides levels in surface waters in agricultural-forestry basin in southern Chile. Chemosphere. 57, 763-770.

The Pesticide Properties DataBase (PPDB) 2013. Developed by the Agriculture \& Environment Research Unit (AERU), University of Hertfordshire 2006-2013. Available on http://sitem.herts. ac.uk/aeru/footprint/index2.htm (last visit February 6,2015$)$.
Qiu, H., Lu, L.V., Pan, B., Zhang, Q-J., Zhang, W., Zhang, Q-X. 2009. Critical review in adsorption kinetic models. J. Zhejiang Univ. Sci. A. 10, 716724.

Sadzawka, A., Grez, R., Carrasco, M., Mora, M.L. 2006. Método de análisis recomendados para los suelo Chilenos. Comisión de Normalización y Acreditación Sociedad Chilena de la Ciencia del Suelo.

Schwarzenbach, R.P., Gschwend, P.M., Imboden, D.M. 1993. Environmental Organic Chemistry. John Wiley \& Sons, New York.

Tomlin, C. 1995. The Pesticide Manual, 10th ed. British Crop Protection Council, Farnham, Surrey, UK.

Ulen, B., Larsbo, M., Kreuger, J., Svanback, A. 2014. Spatial variation in herbicide leaching from marine clay soil via subsurface drains. Pest Manag. Sci. 70, 405-414. 